\title{
POSSIBLE MODEL(S) FOR POST-BREXIT EU-UK RELATIONS IN LIGHT OF EXISTING CONSTRAINTS IN EU LAW
}

Narin IDRİ*

Research Article

\begin{abstract}
This article aims to identify the constraints flowing from EU law that will limit both the content and form of the post-Brexit EU-UK relationship. These legal constraints will reveal what the room for manoeuvre will be in determining the future relationship. Determining what lies within and outside the boundaries set by these constraints will help shed light on the possible future models on which this relationship could be based. Even though these boundaries are far from being clear and precise, they will nevertheless help eliminate some of the pre-existing relationship models, leaving us with the possible options, which could be further adapted to suit the needs of the future relationship.
\end{abstract}

Keywords: Future EU-UK Agreement, Legal Constraints, Principle of Autonomy, Post-Brexit Models

\section{“AB Hukuku Kısıtları Işı̆̆ında Brexit Sonrası AB-Birleşik Krallık İlişkileri İçin Olası Model(ler)"}

$\ddot{O} z$

Bu makale $A B$ hukukundan kaynaklanan ve gelecekteki $A B-B K$ ilişkilerinin dayanacağı anlaşmayı içerik ve şekil bakımından kısıtlayacak olan etmenleri ortaya çıkarmayı amaçlamaktadır. Bu hukuki kısıtlar gelecekte müzakere edilecek olan anlaşma için tarafların sahip olduğu manevra alanının sınırlarını belirleyecektir. Bu sinırları belirlemekle hangi ilişki modellerinin gelecekteki AB-BK ilişkileri için seçenekler arasında olup hangilerinin olamayacağını tespit etmek mümkün olacaktır.

* Dr. Narin Idriz, Researcher T.M.C. Asser Institute, The Hague. E-mail: n.idriz@asser.nl. ORCID: 0000-0002- 3918-3524

Date of submission: 30/11/2019 Date of Admission: 30/10/2020

The article has been submitted for review in November 2019, and has been briefly updated before its current publication. 
Hâlihazırda var olan bazı ilişki modellerinin elenmesi, hangi modeller üzerinde odaklanılması ve gerekirse hangilerinin adapte edilip gelecekteki AB-BK ilişkileri için temel oluşturabileceğini ortaya koyacaktır.

Anahtar Kelimeler: Gelecekteki AB-BK Anlaşması, Hukuki Kısıtlar, Özerklik İlkesi, Brexit Sonrası İlişki Modelleri

\section{Introduction}

It is impossible to predict the precise content and form of the post-Brexit EU-UK Agreement that will shape the relations between the parties. Many factors will play a role in determining the contours of the new relationship, the majority of which will be linked to the changing political realities in the UK. However, in addition to the political, social and economic factors that are going to play an important role in determining the process, which are more difficult to predict, there are also legal factors in play, which are arguably more predictable. This article will examine the legal factors flowing from EU law that will constrain the content and form of the post-Brexit EU-UK relationship, the main focus being on its trade-related aspects. These legal constraints will reveal what the room for manoeuvre will be in determining the form of the future relationship. Determining what lies within and outside the boundaries set by these constraints will help shed light on possible future model(s) on which this relationship could be based. Even though these boundaries are far from being clear and precise, they will nevertheless help eliminate some of the pre-existing relationship models, leaving us with the possible option(s), which could be further adapted to suit the needs of the future relationship.

To provide a complete picture, it is also worth to briefly mention the most important constraints on the UK, as the focus in the following parts of the article will be on the constitutional constraints flowing from the EU legal order. There are both legal and political constraints on the UK. The UK's legal or constitutional constraints are more difficult to pin down, largely due to its uncodified constitution. Arguably, the UK's commitment to the Good Friday Agreement ${ }^{1}$ is one such constraint. Another legal constraint was revealed in the course of the Brexit process by the Miller judgment delivered by the UK

1 Also called Belfast Agreement, signed on 10 April 1998. It consists of two agreements: the first is the Agreement reached in the multi-party negotiations, and the second is the Agreement between the Government of the United Kingdom of Great Britain and Northern Ireland and the Government of Ireland. Available online at: https://www.gov.uk/government/publications/the-belfast-agreement 
Supreme Court. ${ }^{2}$ However, this judgment is just an example of one of the legal constraints that were at play in the process of the UK's withdrawal from the Union; it is not one of the constraints that will play a role in shaping the framework of the future relationship. As far as the latter are concerned, it is argued that the political constraints on the UK will be decisive. These constraints have also been identified as the UK's red lines. The most important ones are: regulatory autonomy, pursuing an independent UK trade policy, ending free movement of people between the UK and EU Member States, ending the jurisdiction of the CJEU and ending the payment of the UK's compulsory contribution to the EU budget. ${ }^{3}$ These are all the corollaries of taking back "control of borders, laws and money". ${ }^{4}$ One could also add protecting the union between the UK's four parts (England, Wales, Scotland and Northern Ireland) among those red lines. ${ }^{5}$

This article will first, provide a definition of 'legal constraint' (making a distinction between "hard law" constraints and "soft law" constraints), then, identify the procedural and substantive legal constraints that will need to be taken account of in the negotiation process of the future EU-UK agreement. Past opinions and case law of the CJEU will be examined with a view to establishing which elements in those international agreements triggered a negative opinion or resulted in the annulment of Council Decisions concluding those agreements ("hard law" constraints), and how those shortcomings can be remedied. This overview will reveal the most important principles that need to be taken into account and respected if a future agreement between the EU and the UK is to pass the test of compatibility with the Treaties and the constitutional principles underlying the EU legal order.

2 See, $R$ (Miller) v. Secretary of State for Exiting the European Union [2017] UKSC5. In this case, the UK Supreme Court ruled that triggering Article 50 TEU necessitated an Act of the UK Parliament to that effect. The UK government was not allowed to initiate the withdrawal process on its own.

3 HM Government, "The Future Relationship between the United Kingdom and the European Union", Cm 9593, July 2018, p. 1. Political declaration setting out the framework for the future relationship between the European Union and the United Kingdom (Revised Political Declaration), OJ C 384I/178, 12.11.2019, paras. 4, 23, 31, and 37.

4 See, "Theresa May's Lancaster House Speech on future EU-UK relations", 2 March 2018. Available online at: https://www.bbc.com/news/uk-politics-43256183 See also HM Government, "The Future Relationship between the United Kingdom and the European Union", p.1.

5 See "Theresa May's Lancaster House Speech". The Union between the four parts of the UK and their existing relationship, which has been shaped by various devolution settlements, can be identified as a constitutional constraint on the UK. The devolution settlements are available on the following link: https://www.gov.uk/topic/government/devolution 
In order to provide as clear as possible a picture of the future framework of relations, EU guidelines and supplementing directives that provide clues regarding the principles set by the EU regarding the negotiation process and content of the future agreement will be also analysed ("soft law" constraints). This examination will reveal that some of the existing models of relations with third countries are not viable options as they breach the red lines of the UK, while others are not even on offer by the EU. The Political Declaration that accompanied the Withdrawal Agreement negotiated by Prime Minister May ${ }^{6}$ and subsequently, revised by the Johnson government ${ }^{7}$ will be also briefly examined, as it is a useful instrument that reveals the intentions of the parties regarding their future relations. The article will conclude by arguing that, based on the UK's current red lines and constraints flowing from EU law, a looser form of cooperation modelled after WTO rules rather than EU law seems the most viable option.

\section{Definition of 'legal constraints'}

Law does not only constitute and enable government, it also constrains it. ${ }^{8}$ In the EU legal order, it is primarily the founding Treaties that perform this function of constituting, enabling and constraining. The Treaties have been defined as "the constitutional charter" of the EC/ EU in the early case law of the Court of Justice. ${ }^{9}$ They lay down both procedural and substantive constraints on all actors that function within their scope, the main actors being the EU institutions and the Member States. For their actions to be legal and legitimate, all actors have to comply with both types of constraints. In the case of the post-Brexit EU-UK Agreement, this means that the parties will need to follow the appropriate Treaty procedure to conclude the Agreement. The content of the Agreement will determine its legal basis, ${ }^{10}$ which in turn will reveal the institutions involved and the exact procedure to be followed.

${ }^{6}$ Political declaration setting out the framework for the future relationship between the European Union and the United Kingdom (First Political Declaration), OJ C 66I/185, 19.2.2019.

7 Revised Political Declaration, OJ C 384I/178, 12.11.2019.

8 Curtis A. Bradley and Trevor W. Morrison, "Presidential Power, Historical Practice, and Legal Constraint," Columbia Law Review 113 (2013): 1124.

9 See, 'Les Verts', Case 294/83, ECLI:EU:C:1986; Opinion 1/91, ECLI:EU:C:1991:490. Since Article 1(3) TEU provides that "[t]he Union shall replace and succeed the European Community", it could be argued that the Treaties are now "the constitutional charter" of the EU as well.

${ }^{10}$ For example, Art. 207 TFEU is the legal basis for concluding free trade agreements, while broader agreements that go beyond issues of trade are concluded as Association Agreements under Art. 217 TFEU. 
The nature of the EU legal order is an important factor to be taken into account for determining the future relationship between the EU and the UK. As it will be explained below, the "essential" characteristics of this legal order as well as the principles underlying it will constrain the future form of relations. In this context, it will not be an overstatement to say that there is a consensus among EU law scholars that the founding Treaties have gradually evolved over the decades and the EU legal order has transformed into one of constitutional nature. ${ }^{11}$ The main engine behind this constitutionalisation process has undoubtedly been the Court of Justice of the EU, which has been given the task to "ensure that in the interpretation and application of the Treaties the law is observed". ${ }^{12}$

It is noteworthy that there is no definition of the term "constraint" in legal dictionaries ${ }^{13}$ which makes it necessary to coin our own definition. ${ }^{14}$ To use the theoretical underpinning of the concept in legal literature as a starting point for our definition, it should be noted that "the constraining effect of law is typically considered to be based on internal and external considerations (internal (normative) versus external constraints)". ${ }^{15}$ Law functions as an "internal" or "normative" constraint when actors within a legal order have internalized the legal norms flowing from "authoritative text, judicial decisions, or institutional practice". ${ }^{16}$ They act in a particular way out of belief they "ought to" do so. Whereas "external constraints" are characterized by

11 Joseph H. H. Weiler, "The transformation of Europe," Yale Law Journal 100 (1990-1991): 2410; Dashwood qualified it as "constitutional order of states", see Alan Dashwood, "States in the European Union," European Law Review 23 (1998): 201-16; Paul Craig, "Constitutions, Constitutionalism and the European Union," European Law Journal 7, no. 2 (2001): 125; Armin Cuyvers, "The Confederal Comeback: Rediscovering the Confederal Form for a Transnational World," European Law Journal 19, no. 6 (2013): 712-13.

12 See Article 19(1) TEU.

13 Bryan A. Garner, Black's Law Dictionary, 8 ed. (USA: Thomson-West, 2007); Bryan A. Garner, A Dictionary of Modern Legal Usage, 2 ed. (OUP, 2001).

14 The definition of the term in some general dictionaries is as follows: "(1). A constraint is something that limits or controls the way you behave or what you can do in a situation. (2). Constraint is control over the way you behave which prevents you from doing what you would prefer to do." See, John M. Sinclair, Collins Cobuild English Language Dictionary (London: HarperCollins, 1994), 302. Another dictionary provides the following definition: "the act of constraining; restraint, compulsion, necessity; a compelling force; a constrained manner; reserve, self-control. [OF constreign-, stem of constreindre, L constringere (stringere, to draw tight)]". See, Betty Kirkpatrick, The Cassel Concise English Dictionary (London: Cassel Publishers Limited, 1989), 279.

${ }^{15}$ For a more detailed discussion of the term "legal constraint", see Narin Tezcan, "Legal Constraints on EU Member States as Primary Law Makers: A Case Study of the Proposed Permanent Safeguard Clause on Free Movement of Persons in the EU Negotiating Framework for Turkey's Accession" (PhD diss. Leiden University, 2015), 19.

${ }^{16}$ Bradley and Morrison, "Presidential Power, Historical Practice, and Legal Constraint," 1132. 
"[t]he prospect of inefficacy and the threat of sanctions". ${ }^{17}$ Actors refrain from transgressing their competence and authority out of fear of sanctions. For example, in the EU legal order, such a sanction would be triggered when an institution fails to follow the procedure prescribed in the Treaties, and tries to legislate without giving the opportunity to another institution to play its Treaty prescribed role. In such a case, the promulgated legal act can be invalidated by the CJEU for not fulfilling "an essential procedural requirement". ${ }^{18}$ In practice however, "internal" and "external" constraints do not always work independently. ${ }^{19}$

To be more specific about what would qualify as "legal constraint" flowing from EU law for the purposes of this article, the focus will be on two categories: directly effective law (justiciable law), or hard law; and rules and principles that flow from "soft law" instruments adopted in the framework of the Brexit process. The first category of constraints, comprises Treaty provisions, principles and norms that can be invoked before the CJEU and can serve as the basis for the Court to give a negative opinion on the future EUUK agreement, or to invalidate the act concluding the agreement. The invoked "legal constraints" could be directly effective Treaty provisions, as well as general principles of EU law that could be used to check the legality of the future EU-UK agreement. Past agreements that were put to the test by the CJEU will provide us insights as to the rules and principles that have to be respected by the future agreement, if it is not to be sanctioned by annulment. The constraints posed by "hard law" are the most important constraints, "the hard-core legal constraints" if you will. These would have to be respected at all cost in order to avoid the grave repercussions ensuing from a potential CJEU sanction.

The second type of constraints are the so-called "quasi-legal" norms and principles, which can be found in "soft law" instruments issued by the EU institutions in order to guide the process and provide for an "orderly" exit. The sources of rules, principles and procedures described in these documents can be past practice for concluding international agreements, the case law of the CJEU, or inter-institutional consensus attempting to bring order and structure to the exit process of the UK. Many of the rules and procedures found in these

${ }^{17}$ Richard H. Fallon, "Constitutional Constraints," California Law Review 97, no. 4 (2009): 1036; and Bradley and Morrison, "Presidential Power, Historical Practice, and Legal Constraint," 1137-40.

${ }^{18}$ European Parliament v. Council, Case C-65/90, ECLI:EU:C:1992:325, para. 21.

${ }^{19}$ Bradley and Morrison argue that often practices followed out of fear of external sanction become internalized as a result of habit. See, Bradley and Morrison, "Presidential Power, Historical Practice, and Legal Constraint," 1140. 
documents will already have been internalized by actors involved in EU external action who are familiar with the rules in this realm of law. The purpose of putting them together in the Brexit context is to provide clarity, predictability and management of expectations for all involved in the process. Most of the rules and principles in these documents do not have a constraining power similar to that of the "hard law" norms, because they lack the stick, i.e. their breach is not likely to trigger sanctions by the CJEU. They are flexible compared to the "hard law" norms and can be changed if there would be consensus to that effect. However, until such consensus arises, EU institutions and Member States will act in line with these norms and principles they have internalised and follow the well-trodden path to signing international agreements. Political scientists call this logic "path dependency". ${ }^{20}$

The types of legal constraints identified above, also determine the methodology to be followed in this article to identify the constraints flowing from EU law. The second part of this article will identify the deadly sins (principles) of EU law that have in the past led the Court to deliver a negative opinion on draft international agreements. Those sins are to be avoided in the future EU-UK agreement as well. Next, relevant principles and procedures identified in the "Guidelines" and "Negotiating Directives" will be put under the spotlight, as these also provide indication regarding the scope and form of the future relationship.

\section{Identifying (legal) constraints flowing from the EU legal order}

Both the Member States of the EU and its institutions have to act within the constraints set out in the Treaties. As a third state, post-Brexit UK negotiating a future trade or association agreement with the EU would no longer be bound by these constraints. The UK will be bound by its own constitutional framework and priorities set by its government in power at the time of negotiation. Even though the focus in this article is on the constraints on the future agreement that flow from EU law, it is important to note that the constitutional constraints on both parties are important as the resulting agreement is bound to be situated at the intersection of the remaining negotiating room of both parties. It could also be argued that due to its stronger negotiating position, the boundaries set by the EU might be more decisive compared to those of the UK. Eventually, if the parties genuinely work

${ }^{20}$ Paul Pierson, "The Path to European Integration: A Historical Institutionalist Analysis," Comparative Political Studies 29, no. 2 (April 1996): 145-46; Giandomenico Majone, "Unity in Diversity: European Integration and the Enlargement Process," European Law Review 33, no. 4 (2008): 89-112. 
towards reaching a compromise, it is likely that both sides might need to give up some of their steadfast positions.

Before examining the constraints flowing from "soft law" instruments, the following section will first examine the constraints flowing from "hard law". It is risky for the parties to ignore the latter type of constraints in their negotiations for a future agreement, as any Member State or Union institution which is in doubt regarding the compatibility of that agreement with the Treaties of the EU, might request the CJEU to deliver an opinion under Article 218(11) TFEU to that effect. A negative opinion by the court will necessitate the renegotiation of the point(s) found to be incompatible with the Treaties. ${ }^{21}$

\section{A. Hard legal constraints}

Based on an analysis of past cases in which the Court delivered a negative opinion on the conclusion of an agreement with a third country or annulled (parts of) the Council decision concluding such agreement, one can identify some rules and principles that have to be respected when concluding an international agreement. These negative outcomes have been triggered because either the contracting parties have not respected the division of competences between the EU and its Member States, which often had repercussions on the procedure to be followed and institutions involved in concluding the agreement; or, the agreement failed to respect important underlying principles of the EU legal order. In short, one can derive from the case law and opinions of the CJEU both procedural and substantive constraints on concluding international agreements.

\section{Procedural constraints}

As emphasized above, the Treaties both empower and constrain the Member States and Union institutions in their internal as well as external action. Disregarding the procedures laid down in the Treaties carries the threat of effective annulment of an instrument adopted in contravention of Treaty procedures. For example, the CJEU annulled a Council decision on the signature and conclusion of an Agreement on the transfer of suspected pirates with Mauritius on the ground that the Council failed to keep the Parliament

${ }^{21}$ That was the fate of the EEA Court created under the first version of the EEA Agreement. In light of the CJEU's negative opinion, the parties created a new EFTA Court that complied with the requirements of the CJEU. See, Opinion 1/91, and Opinion 1/92 ECLI:EU:C:1992:189. 
fully informed during negotiations as required by Article 218(10) TFEU. ${ }^{22}$ In another case, the Court annulled a Council decision approving a declaration on granting fishing opportunities to Venezuelan vessels in EU waters because the decision was based on a wrong legal basis following which the Parliament was merely consulted, whereas the correct legal basis required its consent. ${ }^{23}$

In many cases the questions on substance and procedure might be intertwined. In cases in which the issue of competence and appropriate legal basis of an international agreement is questioned, which has consequences for the procedure to be followed, the Court would need to draw its conclusions from "a comprehensive and detailed analysis of the relationship between the envisaged international agreement and the EU law in force". ${ }^{24}$ In other words, the Court would need to look into the substance of the agreement (its objectives, context and actual content) and into existing EU law in the relevant area to be able to decide on the issue of competence and appropriate procedure. ${ }^{25}$

It is beyond the scope of this article to provide a typology of international agreements and possible legal bases on which they might be concluded. ${ }^{26}$ Suffice it to say that Member States and the EU have a lot of discretion in deciding the content of an agreement, as long as they make sure the legal basis on which the agreement is concluded takes account of its content. Moreover, they also have discretion in deciding which form that agreement takes, as "Community's [now the Union's] classification of agreements is governed by politics, not law". ${ }^{27}$ For instance, the EU and the UK might choose to conclude several agreements to govern their future relations, one of which could be a Free Trade Agreement (Article 207 TFEU). However, alternatively, they could also choose to go for a single legal framework to govern their future relations, namely an Association Agreement (Article 217 TFEU). Association

22 Parliament v. Council, Case C-658/11, ECLI:EU:C:2014:2025.

${ }^{23}$ Commission v. Council, Joined Case C-103/12 and C-165/12, ECLI:EU:C:2014:2400.

24 Opinion 1/13 ECLI:EU:C:2014:2303, para. 74.

25 See the Court's analysis for every substantive field covered in the Agreement with Singapore to be able to determine whether the EU has exclusive competence to conclude the agreement.

${ }^{26}$ For a more detailed analysis of the topic, see Steve Peers, "EC Frameworks of International Relations: Co-operation, Partnership and Association," in The General Law of E.C. External Relations, ed. Alan Dashwood and Christophe Hillion (Sweet \& Maxwell, 2000); Marc Maresceau, "A Typology of Mixed Bilateral Agreements," in Mixed Agreements Revisited: The EU and its Member States in the World, ed. Christophe Hillion and Panos Koutrakos (Oxford: Hart Publishing, 2010).

27 Peers, "EC Frameworks of International Relations: Co-operation, Partnership and Association," 175. Similarly, Maresceau argues that these agreements occupy a "complex grey zone where law and politics meet". See, Maresceau, "A Typology of Mixed Bilateral Agreements," 16. 
is a very broad and flexible framework for relations. In the words of the first president of the Commission of the EEC, Walter Hallstein, "association can be anything between full membership minus $1 \%$ and a trade and cooperation agreement plus $1 \% \%{ }^{28}$ Such an agreement can cover any topic that is contained in the Treaties under the legal basis of Article 217 TFEU. It can also go on to include topics that are not covered in the Treaties and fall under the competence of Member States, in which case the agreement would need to be concluded as a "mixed agreement". ${ }^{29}$ Due to the length of the approval process of such an agreement, ${ }^{30}$ the parties might prefer to conclude multiple agreements,${ }^{31}$ or provide for the provisional application of its trade-related aspects. ${ }^{32}$

In short, the legal basis and form of a future agreement will be determined by the content of the agreement and by (political) expediency. It is difficult to predict accurately any of these elements in advance; however, it is possible to conclude that there is plenty of leeway for the parties, both in terms of form and method, as long as they abide by the Treaty provisions (and case law of the Court) on concluding international agreements.

\section{Substantive constraints}

Based on the past case law and opinions of the CJEU, it is possible to identify important violations of principles which could trigger a negative

${ }^{28}$ David Phinnemore, Association: Stepping-Stone or Alternative to EU Membership?, ed. Clive Archer and Judy Batt, Contemporary European Studies, 6, (England: Sheffield Academic Press, 1999), 23.

${ }^{29}$ See, Maresceau, "A Typology of Mixed Bilateral Agreements."

${ }^{30}$ Both the EU and its Member States become parties to a "mixed agreement", which then needs to be ratified in each national parliament, in line with the constitutional requirements of each Member State.

${ }^{31}$ For example, after the Court of Justice established that not all topics included in the Free Trade Agreement with Singapore fell under the exclusive competence of the EU in Opinion 2/15 ECLI:EU:C:2017:376, the Commission split the agreement into two. The first agreement, the EU-Singapore Trade agreement covers issues of trade and foreign direct investment liberalisation that are under exclusive EU competence, and the second agreement, the EU-Singapore Investment Protection Agreement covers an issue that is both an EU and Member State competence ("mixed agreement"). While the first agreement entered into force on 21 November 2019 (see Council Decision (EU) 2019/1875, OJ L 294/1, 14.11.2019), the second agreement will enter into force once it is ratified by the EU and all the Member States in line with their internal constitutional requirements.

32 It is common practice to provide for the provisional application of the trade aspects of "mixed agreements". For an example see Council Decision (EU) 2017/38 on the provisional application of CETA, OJ L 11/1080, 14.1.2017. 
opinion or annulment of the instrument concluding the relevant international agreement. The first and most important of these principles is that of the autonomy of the EU legal order. From the Court's first EEA Opinion to its Opinion 2/13 on the Accession to the European Convention on Human Rights (ECHR), the perceived threat of jeopardizing this principle has led to the renegotiation or even demise of important international projects. ${ }^{33}$ To be able to identify what exactly triggered the negative opinions of the Court, so as to avoid making those mistakes in the context of negotiating the agreement establishing the framework for the future EU-UK relations, it is worth having a closer look at agreements that contained elements that violated the principle of autonomy. It is equally important to examine other examples which passed the Court's autonomy test successfully, in order to establish what was done correctly and whether those examples could be replicated in other contexts. The other principles to be examined under this title are the principles of nondiscrimination and the protection of fundamental rights, which have also led to annulment or delivery of a negative opinion by the Court on international agreements. ${ }^{34}$ Lastly, an international agreement concluded with a third state needs to respect peremptory norms of international law, such as the right to self-determination. ${ }^{35}$

\section{a. The autonomy of the EU legal order}

By now it is clearer what the principle of autonomy entails, namely the fact that the Union has a unique constitutional framework, which comprises its founding values (Article 2 TEU), general principles, the provisions of its Charter and the Treaties, all of which in turn determine how its judicial and institutional framework operates and how power/competence between the Union and its Member States is divided. ${ }^{36}$ The Union has a judicial system "to ensure that those specific characteristics and the autonomy of the legal order ... are preserved" ${ }^{37}$ National courts are part of this system in which, together with the CJEU, they ensure judicial protection and full application of EU law.

${ }^{33}$ While the EEA Agreement and the Unified Patent Agreement have been renegotiated after the negative opinions of the Court on those agreements, it seems the negative opinion of the Court on the accession to the ECHR brought the end of the project for the realization of which the Treaty of Lisbon had introduced a specific legal basis under Article 6(2) TFEU. See respectively, Opinion 1/91, Opinion 1/09 ECLI:EU:C:2011:123, and Opinion 2/13 ECLI:EU:C:2452.

34 See, Germany v. Council, Case C-122/95, ECLI:EU:C:1998:94; and Opinion 1/15 ECLI:EU:C:2017:592.

${ }^{35}$ Front Polisario, Case C-104/16 P, ECLI:EU:C:2016:973.

36 Opinion 1/17 ECLI:EU:C:2019:341, para. 110.

37 Opinion 1/17, para. 111. 
However, it is the Court that has "exclusive jurisdiction to give the definitive interpretation of that law". ${ }^{38}$

The Court has tested various international agreements in the past to see if they respect the autonomy of the EU legal order. ${ }^{39}$ While the Court found threats to the principle of autonomy in some cases, it found others respected that principle. It is important to examine both strands of case law as the first one identifies the "hard" legal constraints existing in EU law, while the second one provides a model which can perhaps be emulated and adapted to the needs of the future EU-UK Agreement.

\section{i) Agreements violating the principle of autonomy}

To fully grasp what the Court tries to protect under this principle, it is worth starting our examination with the Court's first opinion in which it found this principle to be under threat, namely its first Opinion on the European Economic Area (EEA) Agreement. This opinion is important since many of the issues identified as threats to the autonomy of the Community legal order back in the 1990s, reappeared later in other opinions of the Court relating to other international agreements, ${ }^{40}$ including Opinion $2 / 13$ on the accession to the ECHR. It should be noted that the overviews of the Court's opinions below are not exhaustive, but merely focus on issues and elements that are instructive as to what is to be avoided or emulated for a future agreement to pass a potential 'autonomy' test by the Court.

\section{aa) Opinion 1/91}

The EEA Agreement is special since it laid down the framework for the most advanced relationship between the EU and a group of third countries, namely Iceland, Liechtenstein and Norway. It is an agreement that extends the EU's internal market to third parties. ${ }^{41}$ It is of paramount importance under this agreement to ensure the EEA is maintained as a homogenous area as envisaged in Article 1 EEA Agreement, which entails that all actors in this area play by the same rules.

To briefly mention the most relevant aspects of Opinion 1/91 for our purpose, the interpretation of the term "Contracting Parties" by the EEA Court

38 Opinion $1 / 17$, para. 111

${ }^{39}$ For an article provising an overview of this case law, see Cristina Contartese, "The autonomy of the EU legal order in the ECJ's external relations case law: From the "essential" to the "specific characteristics" of the Union and back again," Common Market Law Review 54 (2017): 1627-72.

${ }^{40}$ For an example, see Opinion 1/09.

${ }^{41}$ See Schlössle Weissenberg, Case C-452/01, ECLI:EU:C:2003:493, para. 29. 
was found problematic, as the meaning of the term could vary depending on the issue area and division of competences between the Community and its Member States. ${ }^{42}$ Another source of concern was the possibility that even identical provisions could be interpreted differently, due to the different aims and contexts of the EEA and EC agreements. Similarly, the limitation of the duty of conform interpretation with case law of the CJEU delivered only prior to the signature of the agreement (Article 6 EEA) brought a risk of divergent interpretation. ${ }^{43}$ Moreover, the Court rang the alarm bells regarding the potential effect the case law of the EEA Court could have had on the interpretation of EU law. As soon as the EEA Agreement would have entered into force, the agreement together with the measures adopted by the institutions it created, including the case law of its court, would have become part of the Community legal order and thereby also would have bound the Court of Justice. This was unacceptable for the CJEU. It ruled that "in so far as it conditions the future interpretation of the Community rules on free movement and competition [,] the machinery of courts provided for in the agreement conflicts with Article 164 of the EEC Treaty [now Article 19(1) TEU] and, more generally with the very foundations of the Community". ${ }^{4}$

Under the Treaties the Court of Justice retains the sole and exclusive competence for the authoritative interpretation of primary and secondary EU law. According to Article 19(1) TEU, it is the duty of the Court of Justice to "ensure that in the interpretation and application of the Treaties the law is observed". The judicial system envisaged under the EEA Agreement endangered the autonomy of the legal order by conditioning the future interpretation of EU law upon the interpretation provided by another court in the context of another agreement. The Agreement had to be revised in light of the Court's Opinion to ensure that in the case of identical provisions, it would be the Court of Justice alone that has the authority to interpret those provisions (Article 113(3) EEA), and to ensure that future case law of the Court is also incorporated into the EEA legal order. ${ }^{45}$ In its second EEA Opinion, the Court also emphasized the significance of the "Agreed Minute", which stipulated

42 Opinion 1/91, paras. 30-35.

${ }^{43}$ Opinion 1/91, paras. 13-29.

${ }^{44}$ Emphasis added. Opinion 1/91, para. 46

${ }^{45}$ Future judgments of the CJEU however, were to be introduced by the Joint Committee (a political organ) into the EEA legal order (Article 105 EEA). Cases of conflict between the two Courts were also to be resolved by the Joint Committee (Article 111 EEA). Furthermore, an "Agreed Minute" underlined that the decisions of the Joint Committee would not bind the Court in any way. See, Henry G. Schermers, "Opinion 1/91 of the Court of Justice, 14 December 1991; Opinion 1/92 of the Court of Justice, 10 April 1992," Common Market Law Review (1992): 999-1000. 
that the decisions of the Joint Committee (composed of EEA and EU representatives) would not affect the case law of the Court of Justice in any way. According to the Court, this was an essential safeguard, which was indispensable for preserving the autonomy of the Community legal order. ${ }^{46}$

\section{bb) Opinion 2/13}

The Court's second opinion on accession to ECHR was delivered more than twenty years after the EEA Opinions and illustrates that nothing has changed regarding the Court's sensitivity to and caution against threats to the principle of autonomy. After the Court established that the Community does not have competence to accede to the ECHR in its Opinion $2 / 94,{ }^{47}$ a legal basis to that effect was introduced into the Treaties (Article 6(2) TEU) with the Lisbon Treaty revision. Pursuant to that basis, an agreement was negotiated for the Union's accession to the ECHR ${ }^{48}$ which was brought before the Court to check its compatibility with the Treaties. The Court found that some of the elements in the draft accession agreement could adversely affect the autonomy of the EU legal order and some of its special characteristics.

One of the several aspects within the agreement identified by the Court as problematic, was the envisioned "co-respondent mechanism" which left it up to the European Court on Human Rights (ECtHR) to decide who the corespondent would be, the EU and/or its Member States. ${ }^{49}$ This was found to be similarly problematic, as was the case earlier with the proposed EEA Court deciding on the meaning of "Contracting Parties". In the Court's opinion, since this involves an assessment on the division of competences between the EU and its Member States, this mechanism fails to ensure that the specific characteristics of the EU are respected. ${ }^{50}$ Similarly, the implication that in their relations Member States would have to check in every case whether other Member States respect fundamental rights as laid down in the Charter disregards and endangers the principle of "mutual trust" and "is liable to upset the underlying balance of the EU and undermine the autonomy of EU law". ${ }^{51}$ In addition, according to the CJEU, the "prior involvement procedure", laid down in Article 3(6) of the draft agreement, is triggered by the ECtHR in cases

\footnotetext{
${ }^{46}$ Opinion 1/92, paras. 23-24.

${ }^{47}$ Opinion 2/94 ECLI:EU:C:1996:140.

48 47+1(20013)008rev2, Final Report to the CDDH, 10 June 2013.

49 The "co-respondent mechanism" envisioned the involvement of the EU (as co-respondent) in some cases brought against a Member State or a group of Member States and vice versa. For more details, see Article 3(2) to (8) of the Draft Agreement on the EU's Accession to the ECHR.

${ }^{50}$ Opinion 2/13, paras. 224-225 and 235.

${ }^{51}$ Opinion 2/13, para. 194.
} 
in which the CJEU has not yet ruled on a matter that is before the ECtHR. According to the Court, the decision whether it has ruled on a given matter or not entails interpretation of its case law; hence, cannot be left to the ECtHR. ${ }^{52}$ Lastly, the draft agreement did not guarantee sufficiently the CJEU's exclusive jurisdiction under Article 344 TFEU relating to disputes that concern the application and interpretation of EU law. The possibility for Member State to bring such action under Article 33 ECHR was not excluded. ${ }^{53}$

All these arguments, in addition to a few other ones, ${ }^{54}$ resulted in the demise of the draft agreement and perhaps also the EU's aspiration to accede to the ECHR. In light of the Court's earlier EEA Opinions, the conclusions in Opinion 2/13 should not have come as a surprise. The Court has always been very protective of its exclusive jurisdiction with regard to both Article 344 TFEU and its monopoly on the interpretation of EU law. Uniform and consistent interpretation and application of EU law have been an overriding objective of the Court since its early judgments. This means that any future agreement that takes one part of the acquis and has provisions that are identical to EU law, risks triggering the involvement of the Court in one form or another.

\section{ii) Agreements respecting the principle of autonomy}

\section{aa) Opinion 1/00}

The opinion on the draft agreement on a European Common Aviation Area (ECAA), in which the compatibility of the legal supervision system envisaged in the agreement was questioned, is the first opinion in which the Court found no threat to the autonomy of the EU legal order. ${ }^{55}$ While the EEA aims to extend the EU's internal market to third states, the ECAA extends the aviation sector to the participation of third states. However, unlike the EEA, ECAA does not establish an international court, but empowers its Joint Committee to resolve disputes between its parties and interpret the provisions of the ECAA Agreement. ${ }^{56}$

52 Opinion 2/13, para. 239-241.

53 Opinion 2/13, paras. 207-208.

${ }^{54}$ Another important point of concern for the Court was the power given to the ECtHR to review CFSP measures, over which the Court itself has no such competence. See, Opinion 2/13, paras. 249-257

55 Opinion 1/00 ECLI:EU:C:2002:231. For a full analysis, see Fernando Castillo de la Torre, "Opinion 1/00, Proposed Agreement on the Establishment of a European Common Aviation Area," Common Market Law Review 39, no. 6 (2002): 1373-93.

${ }^{56}$ Like the EEA Joint Committee, the ECAA Joint Committee consists of representatives of the Contracting Parties to the Agreement. 
One could observe that the Court's concerns in the EEA Opinions have been taken into account when designing ECAA's legal supervision system. For provisions that are identical to provisions of EU law, Article 23(1) ECAA provides that the interpretation of the CJEU prior to the signature of the Agreement is to be followed. Case law delivered after the signature of the Agreement is to be communicated to the Joint Committee, which determines the implications of the ruling for the ECAA. The decisions of the Joint Committee under this provision have to be in conformity with the case law of the CJEU. Moreover, both the national courts of the Contracting Parties as well as the Joint Committee are able to refer questions to the CJEU when the interpretation of a provision that is identical in substance to a provision of EU law is needed for the resolution of a dispute. The interpretation provided by the CJEU is binding on the parties. ${ }^{57}$ Last but not least, it is ensured that any possible divergence of interpretation will not affect the EU legal order. ${ }^{58}$ All these factors, contributed to the Court finding that "Although the proposed ECAA Agreement affects the powers of the Community institutions, it does not alter the essential character of those powers and, accordingly, does not undermine the autonomy of the Community legal order." 59

This opinion is very useful to illustrate that even in areas of sectoral integration, as soon as one talks about "deep integration", i.e. the extension of EU rules and laws in an area to third parties, there is no way around the jurisdiction of the Court of Justice. Agreements that contain pieces of EU law have to be interpreted by the Court of Justice. The alternative is to cooperate under a looser framework, which does not employ the language of the Treaties or EU secondary law. The following opinion is an illustration of such an example.

\section{bb) Opinion 1/17}

The Comprehensive Economic and Trade Agreement (CETA) between the EU and Canada is described as one of the most progressive and innovative trade agreements signed by the EU. ${ }^{60}$ One of its novel aspects is that in addition to the establishment of a CETA Tribunal, the agreement envisages

57 Opinion 1/00, paras. 23-26 and 30-33.

58 Opinion $1 / 00$, paras. $41-44$

${ }^{59}$ Emphasis added. Opinion 1/00, para. 21.

${ }^{60}$ Elaine Fahey, "CETA and the Global Governance Law: What Kind of Model Agreement is it Really in Law?," European Papers 2, no. 1 (2017): 293; Todd Allee, Manfred Elsig, and Andrew Lugg, "Is the European Union Trade Deal with Canada New or Recycled? A Textas-data Approach," Global Policy 8, no. 2 (2017): 246. 
the establishment of an Appellate Tribunal, and a Multilateral Investment Court in the long-term. Belgium raised concerns regarding a few aspects of the agreement, but what is important for our purposes is the question on the compatibility of the Investor State Dispute Settlement (ISDS) mechanism with the principle of the autonomy of the EU legal order. The source of concern was the fact that there is no obligation and no mechanism in CETA by which the CETA Tribunal could refer to the CJEU questions of interpretation of EU law.

The Court started its examination by stating that "the envisaged ISDS mechanism stands outside the EU judicial system", ${ }^{61}$ as well as the judicial system of Canada. Accordingly, "the power of interpretation and application conferred on the Tribunal is confined to the provisions of the CETA and that such interpretation or application must be undertaken in accordance with the rules and principles of international law applicable between the Parties". ${ }^{62}$ In this context, the Court pointed out what distinguishes CETA from the draft agreement on the unified patent system and from its Achmea ruling on the investment agreements between EU Member States. ${ }^{63}$ The "applicable law" in the context of the unified patent system contained "directly applicable Community law, in particular Council Regulation ... on the Community patent". This meant that the patent court in addition to the agreement creating it, would be required to apply and interpret the future regulation on the Community patent as well as other instruments of EU law. ${ }^{64}$ Similarly, the tribunal established to rule on investment disputes between Member States in Achmea "would be called upon to give rulings on the disputes that might concern the interpretation and application of EU law". ${ }^{65}$ Whereas the CETA Tribunal may consider "the domestic law of a Party as a matter of fact", and "in doing so, the Tribunal shall follow the prevailing interpretation given to the domestic law by the courts or authorities of that Party" ${ }^{66}$ Moreover, "any meaning given to domestic law by the Tribunal shall not be binding upon the courts or the authorities of the other party" ${ }^{67}$ In short, the Tribunal has no power to interpret EU law. If EU law provisions are relevant in the context of a dispute, the Tribunal has to follow the interpretation given to that provision by the CJEU. Moreover, the interpretation followed by the Tribunal has no consequences for the EU legal order.

${ }^{61}$ Opinion 1/17, para. 113

62 Emphasis added. Opinion 1/17, para. 122

${ }^{63}$ Opinion 1/09; and Achmea, Case C-284/16, ECLI:EU:C:2018:158.

${ }^{64}$ Opinion 1/17, para. 124.

${ }^{65}$ Opinion 1/17, para. 126.

${ }^{66}$ Emphasis added. See Article 8.31.2 CETA, and Opinion 1/17, para. 130.

${ }^{67}$ Opinion 1/17, para. 130. 
Another important feature of the agreement is that it confers on the Union the power to determine against whom a case is to be brought: Member States and/or the Union. Thereby, the power of the Court to decide on the division of powers between the Union and its Member States is preserved. ${ }^{68}$ All these features ensure that the autonomy of the EU legal order is safeguarded.

Belgium was also concerned that in examining a case, the CETA Tribunal might have to weigh the freedom to conduct business, i.e. the interest of the investor, against public interests set out in the Treaties and the Charter. If the EU would need to amend or withdraw its legislation because of an assessment made by the CETA Tribunal, this would also breach the principle of autonomy as CETA would be undermining "the capacity of the Union to operate autonomously within its constitutional framework". ${ }^{69}$ In this respect the Court points to Article 28.3.2 CETA, which provides that a Party cannot be prevented from adopting or applying measures in the public interest (to protect public security, public health, public order etc.) and is subject only to the requirement that such measures are not applied in a discriminatory way. In other words, "the CETA Tribunal has no jurisdiction to declare incompatible with the CETA the level of protection of a public interest established by EU measures". ${ }^{70}$

The Court found that CETA was on all accounts an agreement that was compatible with the Treaties. As such it provides a good example for the future EU-UK Agreement. Unlike the EEA, ECAA or the recent Association Agreement with Ukraine, ${ }^{71}$ it does not aim to extend parts of the acquis to third countries. It is a "WTO plus" Agreement. ${ }^{72}$ An analysis of the agreement using the text-as-data approach has demonstrated that a big part of the agreement is indeed novel. Researchers have found that whatever recycled content the agreement has, is more likely to come from past Canadian agreements rather than EU ones, ${ }^{73}$ which means the threat to autonomy that was likely to arise in the context of "integrationist" agreements with identical or similar provisions to those in EU law does not exist in this context, or is rather minimal. ${ }^{74}$

${ }^{68}$ See Article 8.21 CETA, and Opinion 1/17, para. 132.

${ }^{69}$ Opinion $1 / 17$, para. 150.

${ }^{70}$ Opinion 1/17, para. 153. See also, Articles 8.9.1 and 8.9.2 CETA.

71 Association Agreement between the European Union and its Member States, of the one part, and Ukraine, of the other part, OJ L 161/3, 29.5.2014.

72 Fahey, "CETA and the Global Governance Law: What Kind of Model Agreement is it Really in Law?," 294.

73 Allee, Elsig, and Lugg, "Is the European Union Trade Deal with Canada New or Recycled? A Text-as-data Approach," 246-47.

${ }^{74}$ It should be noted that even though the Court cleared the dispute settlement mechanism envisaged in CETA, some scholars argue that its negative effects on the uniform interpretation of EU law cannot be ruled out. See, Giulia Claudia Leonelli, "CETA and the 


\section{b. Protection of fundamental rights}

The Court had ruled already back in its first opinion on the accession to the ECHR that respect for human rights is "a condition of the lawfulness of Community acts". ${ }^{75}$ It repeated this statement in its famous Kadi ruling, ${ }^{76}$ and added that "obligations imposed by an international agreement cannot have the effect of prejudicing the constitutional principles of the EC Treaty" 77 including respect for fundamental rights. The Court has in the past annulled a Council decision approving an international agreement, the Framework Agreement on Bananas, to the extent that it breached the principle of nondiscrimination. ${ }^{78}$ In Kadi, regarding Article 351 TFEU, which concerns agreements Member States have concluded prior to the establishment of the EEC or prior to their accession, the Court underlined that this provision "may in no circumstances permit any challenge to the principles that form part of the very foundations of the legal order, one of which is the protection of fundamental rights" ${ }^{79}$ including the judicial review of Union acts as regards their consistency with those rights.

Recently, the Court gave a negative opinion on the conclusion of an agreement providing for the transfer and processing of Passenger Name Records (PNR) between the EU and Canada on the ground that several provisions of the agreement did not provide for sufficient protection of fundamental rights. ${ }^{80}$ More specifically, the Court found that the agreement interfered with the fundamental rights to respect for private life and the protection of personal data. The PNR agreement envisaged the systematic transfer of PNR data that could be used, retained and further transferred to authorities of other non-Member States for the purpose of combating terrorism and serious transnational crime. The agreement also provided for the storage of that data for a period of five years. As to whether this interference could be justified on grounds of public security, the Court ruled that several provisions

External Autonomy of the EU Legal Order: Risk Regulation as a Test," Legal Issues of Economic Integration 47, no. 1 (2020): 43-69; and Simas Grigonis, "Investment Court System of CETA: Adverse Effects on the Autonmy of EU Law and Possible Solutions," International Comparative Jurisprudence 5, no. 2 (2019): 127-41.

75 Opinion 2/94, para. 34.

76 Emphasis added. Kadi, Joined Cases C-402/05 P and C-415/05 P, ECLI:EU:C:2008:461. The main issue in Kadi was whether a Regulation that gave effect to a Security Council Resolution adopted under Chapter VII of the UN Charter could be subject to judicial review.

${ }^{77}$ Kadi, para. 285.

${ }^{78}$ See Germany v. Council, Case C-122/95, ECLI:EU:C:1998:94. The Court annulled part of the contested decision to the extent that the Agreement provided for the exemption of a category of operators from the export-license system of which it provided for other operators. The case is cited in Kadi, para. 289.

${ }^{79}$ Emphasis added. Kadi, para. 304

80 Opinion $1 / 15$. 
of the agreement were not limited to what was strictly necessary and were not clear and precise. ${ }^{81}$ What was particularly problematic was the transfer of 'sensitive data'. ${ }^{82}$ According to the Court, "[h]aving regard to the risk of data being processed contrary to Article 21 of the Charter, a transfer of sensitive data to Canada requires a precise and particularly solid justification, based on grounds other than the protection of public security against terrorism and serious transnational crime." 83 The Court found no such justification in this case. Moreover, the continued storage of the PNR data of all passengers even after they leave Canada was also not limited to what was strictly necessary. ${ }^{84}$ On the basis of these and other shortcomings ${ }^{85}$ the Court concluded that the envisaged agreement was incompatible with Articles 7 (respect for private and family life), 8 (protection of personal data), 21 (non-discrimination) and 51(1) (scope) of the Charter of Fundamental Rights. ${ }^{86}$

\section{c. Respect for international peremptory norms}

The Court of Justice repeated quite a few times that "international agreements entered into by the Union must be entirely compatible with the Treaties and with the constitutional principles stemming therefrom" ${ }^{87}$ What about norms stemming from international law? Can breaching a peremptory norm of international law be considered a valid ground for annulment of a Council Decision concluding an international agreement? The Court's case law provides a positive answer to that question. Accordingly, the EU is bound "when exercising its powers, to observe international law in its entirety, including not only the rules and principles of general and customary international law, but also the provisions of international conventions that are binding on it". ${ }^{88}$ A good example of this line of case law is the Court's Front Polisario ruling. The applicant, Front Polisario, defining itself as a national

81 Opinion 1/15, paras. 181, 203, 206, 211 and 217.

82 That is "any information that reveals 'racial or ethnic origin, political opinions, religious or philosophical beliefs, trade-union membership', or concerning 'a person's health or sex life"'. See Opinion 1/15, para. 164.

${ }^{83}$ Emphasis added. Opinion 1/15, para. 165.

${ }^{84}$ Opinion $1 / 15$, para. 206.

85 For full analysis of the case, see the annotation by Christopher Kuner, "International agreements, data protection, and EU fundamental rights on the international stage: Opinion 1/15, EU-Canada PNR," Common Market Law Review 55 (2018): 857-82.

${ }^{86}$ For the complete list of the grounds of incompatibility with EU law, see Opinion 1/15, para. 232.

${ }^{87}$ Opinion 1/15, para. 67; Western Sahara Campaign, C-266/16, ECLI:EU:C:2018;118, para. 46; Opinion 1/17, para. 165 .

88 Western Sahara Campaign, para. 47; with further references to Kadi, para. 291; Poulsen and Diva Navigation, C-286/90, ECLI:EU:C:1992:453, para. 9; Air Transport Association of America and Others, C-366/10, ECLI:EU:C:2011:864, para. 101. 
liberation movement representing the Sahrawi people of Western Sahara, challenged the Council Decision that approved the liberalisation agreement on trade in agricultural and fisheries products between the EU and Morocco, as it was interpreted and implemented as covering products from Western Sahara, officially a non-self-governing territory under Moroccan occupation. ${ }^{89}$ The General Court annulled the Council Decision as it found that the Council "failed to fulfil its obligation to examine all the elements of the case before the adoption" of the act concluding the agreement. ${ }^{90}$ According to the General Court, given the fact that the sovereignty of Morocco over Western Sahara was not recognised by the EU, its Member States or the UN, "the Council, in the examination of all the relevant facts of the case ... should have satisfied itself that there was no evidence of an exploitation of the natural resources of the territory of Western Sahara under Moroccan control likely to be to the detriment of its inhabitants and to infringe their fundamental rights". ${ }^{91}$

The Court of Justice reversed the ruling of the General Court on appeal, as it deemed more appropriate to resolve the matter by providing for an interpretation of the territorial scope of the agreement that is in line with the international peremptory principle of self-determination. According to the CJEU, the General Court failed to take into account this principle, which is "a legally enforceable right erga omnes and one of the essential principles of international law". ${ }^{92}$ This meant that the status of Western Sahara as non-selfgoverning territory under international law triggered the "inapplicability of the Association Agreement to that territory". ${ }^{93}$ In this case, there was no need to annul the Council Decision concluding the liberalisation agreement, since there was nothing in it or in the association agreement signed earlier that prevented the parties from interpreting it in line with international law and the principle of self-determination. Arguably, this implies that the Court would have (at least partially) annulled the Council Decision had it been concluded

${ }^{89}$ For the history of Western Sahara and its status under international law, see Council v Front Polisario (Front Polisario II), C-104/16 P, ECLI:EU:C:2016:973, paras. 22-37.

90 Front Polisario v. Council (Front Polisario I), T-512/12, ECLI:EU:T:2015:93, para. 247. For an in-depth discussion of the case, see Eva Kassoti, "The Front Polisario v. Council Case: The General Court, Völkerrechtsfreundlichkeit and the External Aspect of European Integration (First Part)," European Papers 2, no. 1 (2017): 339-56.

${ }^{91}$ Front Polisario I, para. 241.

92 Front Polisario II, para. 88. For a detailed analysis of the case, see Aurora Rasi, "Front Polisario: A step forward in the judicial review of international agreements by the Court of Justice?," European Papers 2, no. 3 (2017): 967-75; Eva Kassoti, "The Council v. Front Polisario Case: The Court of Justice's Selective Reliance on International Rules on Treaty Interpretation," European Papers 2, no. 1 (2017): 23-42.

${ }^{93}$ Front Polisario II, para. 93. 
in breach of the principle of self-determination by explicitly extending the territorial scope of the agreement to Western Sahara.

This does not mean however, that all agreements breaching customary or peremptory rules of international law will lead to annulment. The relationship between EU and international law is complicated as illustrated by the Kadi judgment, in which the Court reviewed the EU measure transposing the UN Security Council resolution for its compatibility with EU rules and principles and not those of international law. In other words, the Court's utilisation of international law in its jurisprudence is rather selective. As Klabbers notes, the Court's main duty is "guarding its own identity. If and when possible it will happily do so in harmony with international law, but if and when impossible to do so harmoniously, the international law will take the back seat". ${ }^{4}$ This means that the constraining power of EU law and its constitutional principles will be much stronger in the context of negotiating the future EU-UK Agreement in comparison to rules and principles flowing from international law.

\section{B. "Soft law" constraints}

After the UK triggered Article 50 TFEU on $30^{\text {th }}$ of March 2017, the European Council and the Council issued guidelines, decisions and supplementary directives for the negotiation of the withdrawal agreement at different points in time in order to guide the process and provide for the "orderly" exit of the UK. In addition to structuring the negotiation process of the Withdrawal Agreement, these documents also lay down rules and principles that are intended to also apply to the negotiations of the future EUUK Agreement, which "can only be finalised and concluded once the UK has become third country". ${ }^{95}$ However, the Union expressed its readiness to "engage in preliminary and preparatory discussions with the aim of identifying an overall understanding of the framework for the future relationship". ${ }^{96}$ That understanding was to be elaborated in a political declaration, which was to accompany the Withdrawal Agreement. As an instrument negotiated between the two parties, rather than being one stemming exclusively from EU law, the contents of the Political Declaration will be examined in the final part of the article.

94 Jan Klabbers, "Völkerrechtsfreundlichkeit? International Law and the EU Legal Order," in European Foreign Policy, ed. Panos Koutrakos (Cheltenham: Edward Elgar Publishing, 2011), 97.

${ }^{95}$ European Council, Guidelines, EUCO XT 20011/17, Brussels, 15 December 2017, para. 6.

${ }^{96}$ Ibid. 
The rules and principles laid down in these guidelines and supplementary negotiation directives are of "soft law" nature. Even though they cannot be challenged in courts of law, ${ }^{97}$ they do set constraints on the process of negotiation as well as the content of the future EU-UK agreement and thereby affect the behaviour of actors involved in the process. Thus, it is worth examining them as far as they provide clues regarding the contours of the future EU-UK agreement. It is worth noting that while some of these principles can be traced back to law, others are more of a political nature. Here too, the line between the political and legal is not always easy to draw. ${ }^{98}$

To begin with, the most important legal principles, the "core principles" identified by the European Council guidelines of 29 April 2017, ${ }^{99}$ and repeated in the Council's Supplementary directives of 29 January 2018 for the negotiation of a withdrawal agreement, ${ }^{100}$ these "general core principles" are "to apply to any agreement with the UK". ${ }^{101}$ They can be boiled down to three main principles. The first one simply states that "any agreement with the United Kingdom will have to be based on a balance of rights and obligations, and ensure a level playing field". ${ }^{102}$ A corollary of this balance is that "a nonmember of the Union, that does not live up to the same obligations as a member, cannot have the same rights and enjoy the same benefits as a member". The second principle concerns the internal market and states that "preserving the integrity of the Single Market excludes participation based on a sector-by-sector approach". ${ }^{103}$ Moreover, the four freedoms "are indivisible and there can be no-cherry picking"'. The third principle was already introduced in the discussion above on hard law constraints and is the principle of autonomy. It dictates the Union "preserve its autonomy as regards its decision-making as well as the Court of Justice of the EU". ${ }^{104}$ Other provisions of the Guidelines on the future framework of relations between the Union and the UK, are more elaborate expressions of these principles. ${ }^{105}$ These principles have also been reiterated in the Directives for the negotiation of a new

${ }^{97}$ To be more precise, one could not challenge a "soft law" instrument in a court since it is not binding; however, one could invoke it if it has an interpretative value in the process of challenging a directly effective (justiciable) provision of a binding instrument, such as a Directive, Regulation or Decision.

98 As Bradley and Morrison argue, law and politics are frequently intertwined. See, Bradley and Morrison, "Presidential Power, Historical Practice, and Legal Constraint," 1124.

${ }^{99}$ European Council, EUCO XT 20004/17, Brussels, 29 April 2017, para. 1.

${ }^{100}$ Council of the European Union, XT 21004/18 ADD 1 REV 2, Brussels, 29 January 2018.

${ }^{101}$ Emphasis added. Ibid, para. 10.

102 Emphasis added. Ibid.

${ }^{103}$ Emphasis added. Ibid.

${ }^{104}$ Emphasis added. Ibid.

${ }^{105}$ See Guidelines of 29 April 2017, paras. 18-23. 
partnership with the UK, ${ }^{106}$ which were annexed to the Council Decision authorising the opening of negotiations for the new partnership agreement. ${ }^{107}$

Even though not identified as one of the "core principles" in the Guidelines or Directives, one needs to add the fourth crucial constraint on the future relations between the EU and the UK, establishing a framework of relations that will respect the Good Friday Agreement and preserve the existing bilateral agreements and arrangements around it, such as the Common Travel Area. ${ }^{108}$ The EU acknowledges the "aim of avoiding a hard border between Ireland and Northern Ireland" in the Guiding Principles for the dialogue on Ireland/Northern Ireland and admits that achieving this aim will require a unique and creative solution. ${ }^{109}$ The importance of the issue is also illustrated by the fact that it was placed among the issues to be negotiated in the first phase of negotiations. ${ }^{110}$ It was not possible to achieve this goal due to the complexity of the issue. It is common knowledge that even the solution agreed upon during the second phase of negotiations by the government of Theresa May proved so controversial that it had to be renegotiated by the government of Boris Johnson. ${ }^{111}$

\section{Implications of the identified legal constraints for the future EU- UK relationship}

It is worth repeating that based on the case law examined above, any future agreement between the EU and the UK will have to respect the constitutional principles of EU law, such as autonomy and respect for fundamental rights, as well as peremptory norms of international law. More specifically, the content of the agreement "must be compatible with the rules

${ }^{106}$ Directives for the Negotiation of a New Partnership with the United Kingdom and Northern Ireland, 5870/20 ADD 1 REV 3, Brussels, 25 February 2020, pp. 4-5.

${ }^{107}$ Council Decision 2020/266 of 25 February 2020 authorising the opening of negotiations with the United Kingdom of Great Britain and Northern Ireland for a new partnership agreement, OJ L 58/53, 27.2.2020.

108 Guiding Principles for the Dialogue on Ireland Northern Ireland, TF50(2017) 15 Commission to UK, 20 September 2017, p. 2

${ }^{109}$ Ibid.

110 The first phase of the negotiations focused on the rights of citizens, the financial settlement, the issues relating to the island of Ireland, and the governance of the Withdrawal Agreement. See, Council of the European Union, Directives on the negotiation of an agreement with the UK and Northern Ireland setting out the arrangements for its withdrawal from the EU, XT 21016/17 ADD 1 REV 2, Brussels, 22 May 2017, paras. 20-43.

111 On the backstop, see Brexit and the backstop: Everything you need to know, UK in a Changing Europe (https://ukandeu.ac.uk/brexit-and-the-backstop-everything-you-need-toknow/, 11 February 2019). 
governing the powers of the EU institutions and with relevant rules of substantive law". ${ }^{112}$ In addition, the agreement should also be concluded in line with procedural rules applicable in EU external relations law. ${ }^{113}$

\section{Hard-law constraints}

What the examination of the opinion under the title on the principle of autonomy reveals is that the closer relations between the two parties are, and the deeper the integration envisaged in a particular area is, the bigger the role to be played by the CJEU. Agreements that employ the language of the Treaties or secondary EU law, have to ensure a mechanism that enables the parties to obtain the opinion of the Court on the interpretation of rules stemming from EU law. In addition, these agreements also need to ensure that a possible interpretation of a provision in the context of such an agreement, does not affect in any way the interpretation of a similar or identical provision in EU law within the EU context. In short, there is a one-way flow of the interpretation of rules and norms: from the EU/CJEU to the legal order/international agreement that borrows those rules and norms from EU law. This eliminates agreements such as the EEA and the Association Agreement with Ukraine, which borrow big chunks of the internal market acquis, from the list of possible models for future relations.

The only case examined above that provides an example of how the jurisdiction of the CJEU is to be avoided, as desired by the UK, is that of CETA. CETA is a 'WTO plus' agreement, which in practice means that instead of relying on rules and concepts that derive from EU law, it uses concepts that derive from WTO and international law. Since CETA also ensures that any possible interpretation of a rule by an arbitration Tribunal will not affect EU law in any way, the Court found the agreement compatible with EU law. CETA is legally speaking waterproof; however, in terms of the access it provides to the EU's internal market, it leaves a lot to be desired. In that sense, it is no secret that the UK's ambitions in terms of desired access to the internal market does not match its readiness to accept the jurisdiction of the Court. As will be briefly elaborated below, the Johnson government revised the Political Declaration negotiated by the government of Theresa May, to ensure the basis of the economic partnership is based on a Free Trade

${ }^{112}$ Western Sahara Campaign, para. 46; see also Opinion 1/15, para. 70.

${ }^{113}$ Western Sahara Campaign, para. 46; Opinion 1/15, para. 70. 
Area that will necessitate no interference or as little as possible interference by the CJEU.

\section{Soft-law constraints}

Juxtaposing the UK's red lines with the "core principles" set by the negotiation Guidelines of the EU, also eliminates some the EU's preestablished models from the list of possible options for a future relationship. The principle that stipulates the exclusion of a sector-by-sector approach means that the Swiss model cannot be on offer. The EU has been unhappy with it for a while and has been working hard to persuade Switzerland to upgrade it. ${ }^{114}$ The indivisibility of the four freedoms means that other models that have been previously considered, for instance in the framework of the ENP, such as the Association Agreement with Ukraine, may also not be on offer in the context of Brexit. ${ }^{115}$ The UK's aversion to foreign judges makes it unlikely to submit to the jurisdiction of the EFTA-Court. The EEA seems to be the least attractive option in light of the UK's red lines, as it also entails a financial contribution and taking on EU rules and regulations governing the internal market (with no contribution beyond decision-shaping), which does not square with "taking back control".

As to the 'Turkey model', it solves one problem while creating others. Creating a Customs Union is the obvious remedy to obviate the need for a hard border in Ireland. However, that option does not allow the UK to follow an independent trade policy, which is one of its red lines. Moreover, one of the EU's core principles dictates that the Union "preserve its autonomy as regards its decision-making", which means that just like Turkey, the UK will be excluded from the decision-making table when the Union takes decisions on the Common Customs Tariff. This exclusion will also not bode well with the UK's goal of "taking back control".

114 The EU and Switzerland negotiated an Institutional Framework Agreement between 20142018, which was not endorsed by the Swiss Federal Council. The EU emphasises that signing the agreement is a precondition for the conclusion of any future agreements and granting further market access. See Council Conclusions on EU relations with the Swiss Confederation, 19 February 2019, para. 9.

115 The Association Agreement with Ukraine does not cover free movement of workers. However, that Agreement might not be attractive for the UK, since it contains various mechanisms of legislative approximation, some of which amount to the incorporation of the EU acquis into Ukrainian law. See, Guillaume Van der Loo, Peter Van Elsuwege, and Roman Petrov, "The EU-Ukraine Association Agreement: Assessment of an Innovative Legal Instrument," EUI Working Papers, no. LAW 2014/09 (2014): 14-19. 
In short, the juxtaposition of EU's core principles with the red lines of the UK, leads us to the same result as above. The remaining model(s) are the WTO-based agreements signed between the EU and Canada, South Korea, Japan and Singapore. However, the problem is that the UK is after a closer economic partnership, one that goes beyond these agreements, especially in the services sector: a 'Canada plus plus' or 'WTO plus plus' so to say. The extra 'pluses' in turn imply 'deeper cooperation/integration' with the EU, which brings us back to the core principle of "a balance of rights and obligations" as well as to the bigger role of the CJEU in cases of "deeper integration'.

An additional factor made explicit in February 2020, signals that even CETA may not be on offer in its current form. ${ }^{116}$ That factor is geography or distance. The negative effect of geography on trade is well-known and documented. ${ }^{117}$ However, spelling it out clearly in a document was helpful for researchers, and hopefully, sobering for politicians. In the few-page document, the Commission's Task Force for Relations with the UK (UKTF) states that "Each agreement with a third country depends on a number of different factors, including distance, and the level and intensity of trade we have with that particular country." "118 According to the Task Force, in the case of the UK, that level and intensity is defined by the UK's past membership into the EU and its internal market. This interconnectedness and geographic proximity are such that it is in the mutual interest of both parties "to agree on fair competition standards between [them], as well as on their effective enforcement". ${ }^{119}$ In other words, due to its level of integration and geographical proximity to the EU, the situation of the UK is not comparable to that of other countries, such as Canada. This implies that no pre-existing agreement or model for relations with a third state will suit the unique relationship between the EU and the UK as a former Member State.

\section{Intentions of the parties laid down in the Political Declaration(s)}

While the "core principles" laid down by the Union can be identified as constraints, it would be more accurate to call the two Political Declarations

\footnotetext{
${ }^{116}$ See, European Commission, Task Force for Relations with the United Kingdom (UKTF), "Trade Agreements: Geography and trade intensity", 19 February 2020. Available online at: https://ec.europa.eu/info/sites/info/files/cwp-20200218-trade-geography2_en.pdf

117 See Anne-Celia Disdier and Keath Head, "The Puzzling Persistence of the Distance Effect on Bilateral Trade," The Review of Economics and Statistics 90, no. 1 (2008): 37-48.

${ }^{118}$ UKTF, "Trade Agreements: Geography and trade intensity", para. 4.

${ }^{119}$ UKTF, "Trade Agreements: Geography and trade intensity", para. 5.
} 
agreed upon by the EU and two successive British governments "statements of intent". ${ }^{120}$ The declarations are not binding, but still quite important as they illustrate what the intentions of the parties are with regard to their future relationship. The fact that there are two of them stems from the fact that there were two UK governments involved in the process, the second one being unhappy with the contents of the first. This part does not provide an overview of the Declarations, but merely focuses on a few points that are deemed important and those that were subject to change. The idea is to demonstrate what the general intentions of the parties are with regard to their future relationship and understand the sensitivities of the Johnson government that resulted in revising some parts of the Political Declaration.

The Political Declaration lays down at the outset the red lines or the "core principles" of both sides as far as the future relationship is concerned. On the EU's part, these are the "core principles" laid down in the April 2017 Guidelines, also examined above; on the part of the UK, those are the sovereignty of the UK, the protection of its internal market, "respecting the result of the 2016 referendum including with regard to its independent trade policy and the ending of free movement of people" between the EU and the UK. ${ }^{121}$

In the first Political Declaration, the parties laid down their intention to establish "the parameters of an ambitious, broad, deep, and flexible partnership across trade and economic cooperation, law enforcement and criminal justice, foreign policy, security and defence and wider areas of cooperation". ${ }^{122}$ This intention was reiterated in the second revised declaration with the further specification that the core of the economic cooperation would comprise "a comprehensive and balanced Free Trade Agreement" ${ }^{123}$ In the revised Declaration, under Part II on the 'Economic Partnership', provisions mentioning the objective of establishing an ambitious, comprehensive, wideranging, economic partnership are followed by a mention of the Free Trade

120 The first Withdrawal Agreement and Political Declaration were endorsed by leaders at a special European Council of 25 November 2018, and published in OJ C 66I/1, 19.2.2019. The revised Withdrawal Agreement and Political Declaration were agreed on at a European Council meeting on 17 October 2019, and published in OJ C 384I/1, 12.11.2019.

${ }^{121}$ Emphasis added. Paragraph 4 of both Political Declarations.

${ }^{122}$ First Political Declaration, para. 3. The different parts of the Declaration also reflect this. Part I: 'Initial Provisions' covers the basis of cooperation, such as "core values and rights". Part II covers the 'Economic Partnership' followed by Part III, which covers the 'Security Partnership'. Part IV contains the 'Institutional and Other Horizontal Arrangements', followed by Part V: 'Forward Process', which lays down the future steps to be taken for the negotiation of the future legal framework for EU-UK relations.

${ }^{123}$ Emphasis added. Revised Political Declaration, para. 3. 
Agreement which will be at the heart of the partnership, ${ }^{124}$ which to some extent downgrades these objectives. The downgrading of the economic ambitions of the agreement has been accompanied by the removal of paragraph 25, under title ' $C$. Regulatory Aspects', which stipulated "the United Kingdom will consider aligning with Union rules in relevant areas". ${ }^{125}$ In addition, the second declaration puts a temporal limit to upholding the common high standards in various fields such as state aid, competition, social and employment standards etc. This limit is the end of the transitional period. ${ }^{126}$

As far as the changes made to Part IV on the 'Institutional and Other Horizontal Arrangements' are concerned, an important institution that remains unchanged and is worth mentioning due to its central role in the future framework of relations is the Joint Committee. It will be composed of Parties' representatives at appropriate level, and will be "responsible for managing and supervising the implementation and operation of the future relationship, facilitating the resolution of disputes, and making recommendations concerning its evolution". ${ }^{127}$ When it is not possible to resolve a dispute within the Joint Committee, the Committee itself or one of the parties is to refer the issue to an independent arbitration panel, whose decision will be binding. If such a dispute raises a question of interpretation of EU law, the arbitration panel needs to make a preliminary reference to the CJEU for a binding ruling. While the obligation to refer remains in the revised text, the sentence providing for a possibility for a party, which considers the arbitration panel has failed to make a preliminary reference when it should have done so, to ask the panel to review its decision and provide reasons for its assessment, has been deleted. This provision, which aimed to safeguard the autonomy of EU law has been replaced by a sentence stating the obvious, i.e. that "there should be no reference to the CJEU where a dispute does not raise such a question". ${ }^{128}$

Some of these changes can clearly be seen as concessions given to the UK in order to break the deadlock. At the end of the day, the Declaration is a non-binding instrument designed to provide a blueprint for the future agreement. Any provision that threatens to breach one of the hard law constraints identified above, such as the principle of autonomy, is bound to be quashed by the CJEU in a negative opinion under Art. 218(11) TFEU. It could be argued that at the time "seeming" to be giving concessions was a necessary

${ }^{124}$ See in particular paragraphs 17 and 22 of the Revised Political Declaration.

${ }^{125}$ Paragraph 25 was under title "C. Regulatory aspects" of the First Political Declaration.

${ }^{126}$ Revised Political Declaration, para. 77.

${ }^{127}$ First Political Declaration, para. 129. Revised Political Declaration, para. 126.

${ }^{128}$ Revised Political Declaration, para. 131. 
evil to push the Withdrawal Agreement through the British Parliament; yet, since the actual positions of the parties have not changed, they are still not able to make any progress in agreeing on the terms and contents of their future relationship.

\section{Conclusion}

The aim of this article was to identify the constraints on the future EUUK agreement that stem from EU law. The first part of the article identified two types of 'legal constraints' for the purpose of this article: constraints flowing from 'hard law' (justiciable/ directly effective provisions of EU law), and those flowing from 'soft law' (non-binding law). The breach of 'hard law' constraints brings about the annulment of a Council Decision concluding an international agreement, which is similar in effect to a negative opinion by the CJEU in the framework of Article 218(11) TFEU, in that both cases necessitate the renegotiation of the international agreement in question. While the 'soft law' constraints do not carry the threat of a sanction, in practice they are followed by the force of habit or as a result of the internalisation of relevant rules and norms. Identifying both types of constraints provides a clearer picture regarding the room for manoeuvre left for the parties negotiating an international agreement.

The second part of the article identified both procedural and substantive 'hard law' constraints that can trigger the annulment of an international agreement. It was established that the procedure to be followed is linked to the content/substance of the agreement. In other words, the substance of an agreement determines the legal basis to be used, which in turn dictates which institutions are involved in the negotiating procedure and adoption of that agreement. As far as identifying the substantive legal constraints on treatymaking is concerned, the article relied on analyses of past cases and opinions in which the CJEU provided a negative opinion on international agreements negotiated between the EU and third parties. These analyses revealed that international agreements need to respect the Treaties, the constitutional principles underlying the EU legal order, and peremptory norms of international law. The most important principles of EU constitutional law were identified as the principle of autonomy and the protection of fundamental rights. The article analysed opinions that provided both negative as well as positive views on international agreements so as to provide concrete examples as to what is to be avoided and what is to be followed and emulated in the future agreement between the EU and the UK. 
After identifying the 'soft law' constraints in the third part of the article, the so-called 'core principles' set by the EU to guide future negotiations, the fourth part examined the implications of the identified constraints (both 'hard law' and 'soft law' constraints) for the future of EU-UK relations. The result of both analyses is that agreements providing for closer cooperation/ deeper integration are not an option for the future relationship as they entail, to a lesser or greater degree, the adoption and implementation of EU laws. That is the case with the EEA, the Association Agreement with Ukraine as well as the Customs Union with Turkey. The third party becomes a 'rule taker', since it is not involved in the adoption process of these rules at the EU level, and has no control over the interpretation of these rules by the CJEU.

The remaining option is a looser form of cooperation based on WTO rules rather than EU law. The EU has signed such agreements recently with Canada, Japan, Singapore and South Korea. While those agreements provide ambitious forms of cooperation for states and entities that are geographically apart, they will not satisfy the needs of the UK economy, which has been an integral part of the internal market for almost half a century. The UK and its businesses are enmeshed in the production processes and value chains of that market. The latest revisions in the Political Declaration clearly state that the future economic partnership will be based on "a comprehensive and balanced Free Trade Agreement". In addition, the revisions also prepare the ground for future divergence in regulatory standards and give one the impression that the EU and the UK might choose for a looser type or relationship. However, the fact that the UK is ready to accept the jurisdiction of the Court of Justice, despite attempting to limit that role to a minimum, implies that there is still a possibility that cooperation between the two might go beyond the terms of a Free Trade Agreement based on WTO rules. Eventually, the precise content and form of the agreement will depend on the political realities in the UK, the EU and the world at the time they are ready to conclude the negotiations on their future relationship. 


\section{Bibliography}

Allee, Todd, Manfred Elsig, and Andrew Lugg. "Is the European Union Trade Deal with Canada New or Recycled? A Text-as-Data Approach." Global Policy 8, no. 2 (2017): 246-52.

Bradley, Curtis A., and Trevor W. Morrison. "Presidential Power, Historical Practice, and Legal Constraint." Columbia Law Review 113 (2013): 1097-161.

Brexit and the Backstop: Everything You Need to Know. UK in a Changing Europe (https://ukandeu.ac.uk/brexit-and-the-backstop-everything-you-need-to-know/: 11 February 2019).

Castillo de la Torre, Fernando. "Opinion 1/00, Proposed Agreement on the Establishment of a European Common Aviation Area." Common Market Law Review 39, no. 6 (2002): 1373-93.

Contartese, Cristina. "The Autonomy of the EU Legal Order in the Ecj's External Relations Case Law: From the "Essential" to the "Specific Characteristics" of the Union and Back Again." Common Market Law Review 54 (2017): 1627-71.

Craig, Paul. "Constitutions, Constitutionalism and the European Union." European Law Journal 7, no. 2 (2001): 125-50.

Cuyvers, Armin. "The Confederal Comeback: Rediscovering the Confederal Form for a Transnational World." European Law Journal 19, no. 6 (2013): 711-38.

Dashwood, Alan. "States in the European Union." European Law Review 23 (1998): 201-16.

Disdier, Anne-Celia, and Keath Head. "The Puzzling Persistence of the Distance Effect on Bilateral Trade." The Review of Economics and Statistics 90, no. 1 (2008): 37-48.

Fahey, Elaine. "CETA and the Global Governance Law: What Kind of Model Agreement Is It Really in Law?". European Papers 2, no. 1 (2017): 293-302.

Fallon, Richard H. "Constitutional Constraints." California Law Review 97, no. 4 (2009): 975-1037.

Garner, Bryan A. Black's Law Dictionary. 8 ed. USA: Thomson-West, 2007.

. A Dictionary of Modern Legal Usage. 2 ed.: OUP, 2001.

Grigonis, Simas. "Investment Court System of CETA: Adverse Effects on the Autonmy of EU Law and Possible Solutions." International Comparative Jurisprudence 5, no. 2 (2019): 127-41.

Kassoti, Eva. "The Council v. Front Polisario Case: The Court of Justice's Selective Reliance on International Rules on Treaty Interpretation." European Papers 2, no. 1 (2017): 23-42. 
. "The Front Polisario v. Council Case: The General Court, Völkerrechtsfreundlichkeit and the External Aspect of European Integration (First Part)." European Papers 2, no. 1 (2017): 339-56.

Kirkpatrick, Betty. The Cassel Concise English Dictionary. London: Cassel Publishers Limited, 1989.

Klabbers, Jan. "Völkerrechtsfreundlichkeit? International Law and the EU Legal Order." In European Foreign Policy, edited by Panos Koutrakos. Cheltenham: Edward Elgar Publishing, 2011.

Kuner, Christopher. "International Agreements, Data Protection, and EU Fundamental Rights on the International Stage: Opinion 1/15, EU-Canada PNR." Common Market Law Review 55 (2018): 857-82.

Leonelli, Giulia Claudia. "CETA and the External Autonomy of the EU Legal Order: Risk Regulation as a Test." Legal Issues of Economic Integration 47, no. 1 (2020): 43-70.

Majone, Giandomenico. "Unity in Diversity: European Integration and the Enlargement Process." European Law Review 33, no. 4 (2008): 457-81.

Maresceau, Marc. "A Typology of Mixed Bilateral Agreements." In Mixed Agreements Revisited: The EU and Its Member States in the World, edited by Christophe Hillion and Panos Koutrakos, 11-28. Oxford: Hart Publishing, 2010.

Peers, Steve. "EC Frameworks of International Relations: Co-Operation, Partnership and Association." In The General Law of E.C. External Relations, edited by Alan Dashwood and Christophe Hillion: Sweet \& Maxwell, 2000.

Phinnemore, David. Association: Stepping-Stone or Alternative to EU Membership? Contemporary European Studies, 6. Edited by Clive Archer and Judy Batt. England: Sheffield Academic Press, 1999.

Pierson, Paul. "The Path to European Integration: A Historical Institutionalist Analysis." Comparative Political Studies 29, no. 2 (April 1996): 123-63.

Rasi, Aurora. "Front Polisario: A Step Forward in the Judicial Review of International Agreements by the Court of Justice?". European Papers 2, no. 3 (2017): 96775.

Schermers, Henry G. "Opinion 1/91 of the Court of Justice, 14 December 1991; Opinion 1/92 of the Court of Justice, 10 April 1992." Common Market Law Review (1992): 991-1009.

Sinclair, John M. Collins Cobuild English Language Dictionary. London: HarperCollins, 1994.

Tezcan, Narin. "Legal Constraints on EU Member States as Primary Law Makers: A Case Study of the Proposed Permanent Safeguard Clause on Free Movement of 
Persons in the EU Negotiating Framework for Turkey's Accession." PhD diss., Leiden University, 2015.

Van der Loo, Guillaume, Peter Van Elsuwege, and Roman Petrov. "The EU-Ukraine Association Agreement: Assessment of an Innovative Legal Instrument." EUI Working Papers, no. LAW 2014/09. (2014).

Weiler, Joseph H. H. "The Transformation of Europe." Yale Law Journal 100 (19901991): 2403-83. 